\title{
Corporate governance and information asymmetry
}

\author{
Hamid Salehi", Hamideh Rezaie and Farideh Ansari
}

Department of Accounting, College of graduate studies, Science and Research Branch of Kohgiluyeh and Boyer-Ahmad, Islamic Azad University, Yasouj, Iran

\section{H R O N I C L E}

Article history:

Received January 28, 2014

Accepted 25 June 2014

Available online

June 302014

Keywords:

Corporate governance

Information asymmetry

Institutional ownership

Majority ownership

Board of directors

\begin{abstract}
A B S T R A C T
The purpose of this study is to investigate the impact of some corporate governance mechanisms on information asymmetry. From among different mechanisms of corporate governance, the number of board members who were not responsible, ownership concentration and the percentage of institutional ownership are considered. Time scale of the study includes the years from 2005 to 2011. Sampling was performed among all the companies accepted in Tehran Stock Exchange using systematic removal method. This sample includes 504 companies-years. This is a post-event study. Experimentally, this study lies in accounting proving research areas and it is based on financial statements of the firms, and regarding purpose is application. Descriptive method has been used in this study. The findings show that there was a positive and significant relationship between the number of board members who are not responsible and the percentage of institutional ownership from the one side, and information asymmetry from the other. In addition, the findings show a negative significant relationship between ownership concentration and information asymmetry.
\end{abstract}

\section{Introduction}

One of the influential factors in investment decisions is to have appropriate and new information. Since the required information is asymmetrically distributed among people, it can cause various results about one subject. Therefore, this information is important for decision makers and the quality of distributing information should be accurately evaluated (Ghaemi \& Vatanparast, 2005). Information asymmetry in economic sciences is considered as an economic system based on incomplete information; i.e., a system in which some people have more information than others, and have information advantage (Spence et al., 1970). It may influence the firm's performance, and, hence, to solve this problem, it is assumed that as corporate governance is stronger in general, information asymmetry will be less.

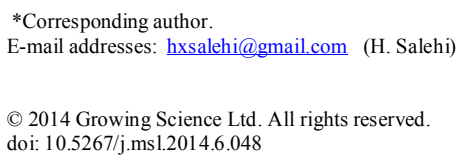


Corporate governance is a term that one or two decades ago, except for a few of researchers and stakeholders, had no meaning for others, but is now a major concern and a main argument for the Board of the company, the university and political talks all over the world. Some incidents and several important trends led to growing interest of communities towards corporate governance debate. Following these events, corporate governance became not only a term commonly used by researchers, but also researchers, policy-makers, and the corporate world anywhere in the world identified macroeconomic outcomes, and potential long-term distribution systems and poor corporate governance. Many studies indicate that better corporate governance mechanisms may increase quality and quantity of information disclosed by firms and reduce asymmetric information. Kanagaretnam et al. (2007) showed that the company with strong corporate governance has lower information asymmetry around the announcement of its profits. On the other hand, based on previous research, such as Shleifer and Vishny (1997) the effective Board was considered the most distinctive and important internal tool for monitoring; the greater the number of members who are not responsible, it can be said that more monitoring is applied and thus information asymmetry is less. Shleifer and Vishny (1997) call the percentage of institutional stock ownership as an internal lever for control.

In this study the effect of different mechanisms of corporate governance on information asymmetry is investigated. From among mechanisms of corporate governance, three of them namely the number of board members who are not responsible, ownership concentration and percentage of selected institutional ownership and its impact on information asymmetry are measured. Therefore, in this study, three main hypotheses are discussed within each the relationship between one of the mechanisms of corporate governance with information asymmetry is studied.

The results of this study in Tehran Stock Exchange for the years 2005 to 2011 for a sample of companies are that there is a positive and significant relationship between the number of board members who are not responsible and the percentage of institutional ownership on the one hand and information asymmetry on the other. Results also show a significant negative relationship between ownership concentration and information asymmetry.

\section{Theoretical Foundations and Literature Review}

Spence et al. (1970) are believed to be the first who established a theory on information economic known as information asymmetry theory. In economic science, this theory led to the creation of a field called economic system based on incomplete information. In the economic system based on incomplete information, some people are officially identified who have informational advantage compared with others. Two major types of asymmetric information are adverse selection and moral hazard. Adverse selection is a type of asymmetric information, which, in economic system, one or more people in contract or a potential transaction have information advantage compared with others. Moral hazard is a type of asymmetric information, which, in economic system, one or more parties to the contract or transaction can see their demands are done in a trade, but the other side cannot see the event. (Spence et al., 1970). Akerlof (1970) initially introduced the concept of information asymmetry. His idea was that one of the parties has an informational advantage over the other. Klein et al. (2002) observed that information asymmetry refers to the concept that individuals within the company, like executives, have better information on asset values and investment opportunities as compared with other market participants. According to agency theory, agency problems are built because of the divergence of interests between representatives and employers (Jensen \& Meckling, 1986; Shleifer \& Vishny, 1997; Miller, 2002). In summary, the asymmetric information can be created through a conflict of interest between various groups (Morgado \& Pindado, 2003). Because many employers cannot completely measure and monitor the behavior of the agents (managers) (Haniffa \& Hudaib, 2006), agency costs are created. According to Shleifer and Vishny (1997), corporate governance is associated with methods in which financial resource 
suppliers, regarding appropriate output from their investment, will remain sure. Parkinson's definition (1994) is also of the view, which is consistent with agency theory: "corporate governance is the process of monitoring and controlling to ensure the performance of company director with the benefits of shareholder". The other definition implies determining the value added by the firm and its allocation among stakeholders who have relationship with firms (Zingales, 1998). The definition of Hassasyeganeh (2006) is consistent with the stakeholder's theory: "corporate governance is laws, regulations, structures, processes, cultures, and systems that contribute to achieving the goals of accountability, transparency, justice, and the rights of stakeholders". This definition can be considered as extracts and abstracts of most definitions of corporate governance, which has so far been provided.

Corporate governance mechanisms are whereby an indirect and probably incomplete tool in which stakeholders (employers) attempt to reduce the cost of agency through changing the behavior of directors who are representatives of the shareholders (Deshmukh, 2005; Kanagartenam et al., 2005, 2007; Rutherford \& Buchholtz, 2007; Chen et al., 2007, 2010). The actions of managers can be reduced through reducing information asymmetry in two ways, one directly through incentives and the other indirectly through monitoring. Managers, through an incentive by getting rewards disclose the level of their attempts, which thus information asymmetry reduces associating with their actions. Besides, through regulatory mechanisms such as separating the roles of chairman from CEO or increasing the number of directors who are not responsible in the board, information asymmetry can be reduced. Regulatory mechanisms are like a window through which shareholders can observe the behavior of their managers. Not much research has been executed on the relationship between the nature of a firms' corporate governance and the degree of information asymmetry. Most of the evidences achieved in this regard are contradictory. Shleifer and Vishny (1997), Perotti and Thadden (2003), Pawlina and Renneboog (2005) and Florackis and Ozkan (2009) reported that large shareholders could reduce information asymmetry and improve long-term performance. In contrast, Heflin and Shaw (2000), O'Neill and Swisher (2003) and Fehle (2004) found that bigger institutional ownership was associated with greater information asymmetry.

Many other studies that investigate the relationship between corporate governance and information asymmetry are usually concerned with limited characteristics or individual corporate governance mechanisms. Hillier and Mac Kolgan (2006), Kanagartnam et al. (2007) and Holm and Schuler (2010) found that board independence reduces information asymmetry. Peasnell et al (2005) expresses the opinion that the independence of the board supports the accuracy of financial statements. Wruck (1993) and Kang et al (2006) investigated the importance of bonus compensation for executives in reducing agency problems and lowering information asymmetry. Kay and Scott Lee (2010) and Chen et al. (2010) stated that high levels of free cash flow and external financing need reducing information asymmetry among firms and strengthening the impact of corporate governance practices on the value of the firm. Nouravesh and Ebrahimi Kordlar (2005), in a study, examined the relationship between institutional shareholders and information asymmetry. They reported that in firms with higher institutional ownership, compared with those that have low institutional ownership, the prices of stock incorporated more information on future profits. Rahimian et al. (2009) studied the relationship between some mechanisms of the corporate governance and information asymmetry in firms accepted in Tehran Stock Exchange over period 2004-2009. They reported that there was not any significant correlation between internal auditing unit and the ratio of management. However, there was a significant negative relationship between the ownership of institutional investors and information asymmetry. Rahmani et al. (2010) investigated the relationship between institutional ownership and stock liquidity in Iran. They explained that there was a positive significant relationship between the ratio of institutional ownership and stock liquidity, and that the institutional ownership concentration reduces stock liquidity of companies. The criteria considered to determine information 
asymmetry in this study is the domain of the proposed price for buying and selling of stock and the model of Venkatesh and Chiang (1986) has been used for its calculation. The difference of proposed price for buying and selling roots in unusual supply and demand. Unusual supply and demand are created due to the existence of confidential information. At the time of bad confidential news, the supply of the stock increases and the proposed price for selling decreases. On the contrary, in case of good confidential news, the demand increases and the proposed price for buying increase too. If confidential information does not exist, the effects of general information by market-makers is reflected in stock price; that is, the market-makers lead the price towards an appropriate level, as a result, unusual sales do not take place (Ghaemi \&Vatanparast, 2005)

\section{Research Methodology}

This is a post-event study. In this research, the purpose is to investigate the relationships among variables, and data is collected and analyzed from environment that is to some extend natural or from the past events without the interference of the researcher. Experimentally, this research is located in accounting fixing research and is based on real information in financial statements of firms; regarding the purpose, this study is application. Descriptive method is used in this study. Descriptive research included a set of methods whose purpose is to describe examined status or phenomenon.

In this study, the fundamental issue is to examine the relationship between the number of board members who are not responsible, institutional shareholders ownership and ownership concentration with information asymmetry. Therefore, the research hypotheses are as follows:

Hypothesis 1: The relationship between the number of board members who are not responsible and information asymmetry is significant.

Hypothesis 2: The relationship between the percentage of institutional stock ownership and information asymmetry is significant.

Hypothesis 3: The relationship between ownership concentration and information asymmetry is significant.

The sample of firms is accepted firms in Tehran Stock Exchange selected through systematic removal method. Therefore, from among all the companies accepted in Tehran Stock Exchange, except the investment companies, banks, and insurance companies, companies were selected that had been accepted before 2005. In addition, the end of their financial year was the end of March, and during the study period had no change in financial year. Based on these limitations, 72 companies were selected as sample. The period is during the years between 2005 and 2011. Data has been collected through observation and reviewing documents including financial statement information of companies and the information concerning the company's stock. In this research, for the formulation of the research literature, library method and to test the hypothesis, the information in financial statements and associated notes of companies of Tehran Stock Exchange has been used.

\section{Data Analysis}

The main purpose is to provide a model based on accounting variables for prediction, Pearson correlation and multivariate regression to present model are utilized. The following model is used to test the hypotheses.

$\operatorname{SPREAD}_{\mathrm{i}, \mathrm{t}}=\beta_{0}+\beta_{1} \mathrm{OUT}_{\mathrm{i}, \mathrm{t}}+\beta_{2} \mathrm{OWN}_{\mathrm{i}, \mathrm{t}}+\beta_{3} \mathrm{CONC}_{\mathrm{i}, \mathrm{t}}+\beta_{4} \mathrm{SIZE}_{\mathrm{i}, \mathrm{t}}+\beta_{5} \mathrm{SALE}_{\mathrm{i}, \mathrm{t}}+\beta_{6} \mathrm{PROF}_{\mathrm{i}, \mathrm{t}}+\beta_{7}$ $\mathrm{LEV}_{\mathrm{i}, \mathrm{t}}+\varepsilon_{\mathrm{i}, \mathrm{t}}$

Dependent variable in this model is information asymmetry stated as SPREAD. To measure information asymmetry, the difference between bid and offer prices of shares are used. To do this, the following formula is used: 
SPREADit $=(A P-B P) \times 100 /(A P+B P) \div 2$

where SPREAD is the amplitude difference between the price of an offer to buy or sell stocks; AP represents the average price of selling company stock; and BP states the average price of an offer to buy shares of the company. Independent variables of the model consists of the members of the Board who are not responsible (OUT), institutional ownership (OWN), and majority ownership or ownership concentration (CONC High). Institutional shareholders include banks, insurance companies, and investment firms. Institutional shareholders include board member and non-member board. Ownership concentration represents the percentage of stocks in the hands of three first main shareholders. Model control variables include firm size (SIZE), sales growth (SALE), financial leverage (LEV), and profitability (PROF). Firm size is measured by calculating the natural logarithm of the value of company assets. Sales growth, leverage, and profitability are calculated by the following method.

Sales growth $=$ (sales of the current year - sales of the previous year) / sales of previous year Financial leverage $=$ long-term debt $/$ total assets

Profitability $=$ operating cash flow / total assets

Central indicators and dispersion for research variables for descriptive analysis of the variables are determined before testing hypotheses. Mean will be calculated as the most central index with standard deviation as the most important distribution indices. Standard deviation shows data scattering. This is executed to provide a holistic view of population and the identification. Therefore, the descriptive statistics of the variables is included. Descriptive statistics, for the entire year is shown in Table 1 and Table 2 shows the results of Pearson correlation coefficient matrix.

\section{Table 1}

Descriptive statistics of research variables

\begin{tabular}{lcccc}
\hline Variable & Minimum & Maximum & Mean & Standard deviation \\
\hline Information asymmetry & 0.0007 & 5.812 & 1.797 & 0.945 \\
The number of members who are not responsible & 0 & 6 & 2.85 & 1.264 \\
Institutional Ownership & 0 & 0.98 & 0.417 & 0.334 \\
Ownership concentration & 0.24 & 0.99 & 0.726 & 0.178 \\
Company size & 3.821 & 8.249 & 5.79 & 0.6354 \\
Sales growth & -0.667 & 2.152 & 0.184 & 0.3018 \\
Profitability & -0.657 & 0.955 & 0.152 & 0.187 \\
Financial Leverage & 0.0006 & 0.574 & 0.0888 & 0.0987 \\
\hline
\end{tabular}

Table 2

Pearson correlation coefficient matrix

\begin{tabular}{|c|c|c|c|c|c|c|c|}
\hline Variable & 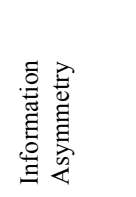 & 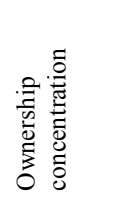 & 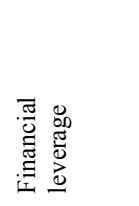 & 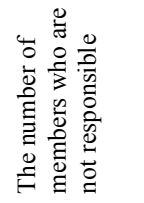 & 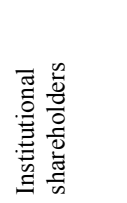 & 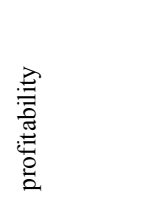 & 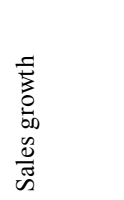 \\
\hline Information asymmetry & 1 & & & & & & \\
\hline Ownership concentration & $0.3(0.00)$ & 1 & & & & & \\
\hline Financial leverage & $0.03(0.19)$ & $0.278(0.00)$ & 1 & & & & \\
\hline $\begin{array}{l}\text { The number of members who } \\
\text { are not responsible }\end{array}$ & $0.412(0.00)$ & $0.297(0.00)$ & $0.337(0.000)$ & 1 & & & \\
\hline Institutional shareholders & $0.379(0.00)$ & $0.337(0.00)$ & $0.398(0.000)$ & $0.301(0.000)$ & 1 & & \\
\hline profitability & $-0.046(0.30)$ & $0.046(0.30)$ & $0.007(0.871)$ & $-0.028(0.520)$ & $0.048(0.28)$ & 1 & \\
\hline Sales growth & $0.398(0.00)$ & $0.305(0.00)$ & $0.405(0.000)$ & $0.254(0.000)$ & $0.599(0.00)$ & $0.008(0.857)$ & 1 \\
\hline Company size & $0.424(0.00)$ & $0.221(0.00)$ & $0.212(0.000)$ & $0.201(0.000)$ & $0.365(0.00)$ & $-0.147(0.00)$ & $0.298(0.00)$ \\
\hline
\end{tabular}


As it can be seen, the sign of the relationship of the number of members who are not responsible and the percentage of institutional shareholders with the variable of information asymmetry is positive and significant, and the direction of the ownership concentration relationship with information asymmetry variable is negative and significant. Variables of sales growth and firm size also have a significant and positive relationship with information asymmetry and profitability variable has negative relationship but insignificant and financial leverage had positive but insignificant relationship with information asymmetry.

According to Pearson correlation coefficients, it can be said that the first hypothesis, which expresses a significant relation between the number of board members who are not responsible and information asymmetry; the second hypothesis is based on the significant relationship between the percentage of institutional shareholders ownership; and the third hypothesis based on the significant relationship between ownership concentration and information asymmetry are approved.

The results of the model analysis are shown in Table 3. According to the results listed in Table 3, except for a significant level of profitability and financial leverage level control variables, the significance of other variables is less than 0.05 . So, all three hypotheses, which claimed there is significant relationship between the mechanisms of corporate governance and information asymmetry, are confirmed. Among the mechanisms of corporate governance, the relationship of the number of board members who are not responsible and institutional ownership with asymmetric information is positive and significant, and ownership concentration has negative and significant relationship with information asymmetry. According to Durbin-Watson statistics, it can be realized that error terms are not correlated. Determining factor shows the strength of the resulting independent variables in explaining the dependent variable. According to the F statistics, one realizes that the regression model is significant.

\section{Table 3}

Results of fitted model

\begin{tabular}{lccc}
\hline Dependent variable: information asymmetry & Coefficient & t Statistics & Sig. \\
\hline Constant factor & -0.685 & -1.805 & 0.0716 \\
Profitability & 0.024322 & 0.132503 & 0.8946 \\
Company size & 0.355522 & 6.842383 & 0.000 \\
Sales growth & 0.410533 & 3.752264 & 0.0002 \\
Financial Leverage & 0.476169 & 1.401740 & 0.1616 \\
The number of members who are not responsible & 0.175 & 6.352 & 0.000 \\
Ownership concentration & -0.412657 & -2.185461 & 0.0293 \\
Shares Institutional owners. & 0.043447 & 2.921728 & 0.0206 \\
\hline
\end{tabular}

F-statistics $=38.59628$ P-Value $=0.000$ Durbin-Watson statistics $=1.8575552$ Adjusted R-Square $=0.343491$

\section{Conclusion}

The results of this study showed that there was a positive and significant relationship between the number of board members who are not responsible and institutional ownership on the one hand and information asymmetry on the other. It means by increasing the number of board members who are not responsible and institutional ownership, information asymmetry increases. In addition, research shows that there was a significant negative relationship between ownership concentration and information asymmetry. It means; as the concentration of ownership increases, the degree of information asymmetry of companies reduces. The positive relationship obtained between the number of board members who are not responsible and asymmetry of information in this study contradicts with the results of Hillier and Mac Kolgan (2006), Kanagartenam et al. (2007), Holm and Schøler (2010) who found that the independence of board of directors reduces information asymmetry. In this research, the managers who are not responsible are those who would not wish to act as executive, and it is supposed that they were independent of the firm while they may not be. Therefore, 
traditional differences in defining executive managers and without responsibility may be unable to determine potential benefit contradictions between managers without responsibility and the company in whose board they are involved.

The positive relationship between institutional ownership and information asymmetry found in this study is consistent with the results of Heflin and Shaw (2000), O'Neil and Swisher (2003) and Fehleh (2004) who found that bigger institutional ownership was associated with bigger information asymmetry. Note that Rahimian et al. (2009) did not find any significant relationship between institutional ownership and information asymmetry. The negative relationship between ownership concentration and information asymmetry found in this study is consistent with the results of Shleifer and Vishny (1997), Perotti and Thadden (2003), Pawlina and Renneboog (2005) and Florackis and Ozkan (2009) who found that large shareholders could reduce information asymmetry and improve long-term performance. In the end, it is worth mentioning that due to improper use of governance mechanisms in Iran, some of these mechanisms do not have the necessity efficiency to reduce information asymmetry.

\section{References}

Akerlof, G. A. (1970). The market for" lemons: Quality uncertainty and the market mechanism. The Quarterly Journal of Economics, 84(3), 488-500.

Cai, C. X., Keasey, K., \& Short, H. (2006). Corporate governance and information efficiency in security markets. European Financial Management,12(5), 763-787.

Deshmukh, S. (2005). The effect of asymmetric information on dividend policy. Quarterly Journal of Business and Economics, 44, 107-127.

Chen, W. P., Chung, H., Lee, C., \& Liao, W. L. (2007). Corporate Governance and Equity Liquidity: analysis of S\&P transparency and disclosure rankings. Corporate Governance: An International Review, 15(4), 644-660.

Chen, W. P., Chung, H., Hsu, T. L., \& Wu, S. (2010). External financing needs, corporate governance, and firm value. Corporate Governance: An International Review, 18(3), 234-249.

Chi, J. D., \& D. S. Lee (2010). The conditional nature of the value of corporate governance. Journal of Banking \& Finance, Vol. 34, 350-361.

Elbadry, A., Gounopoulos, D., \& Skinner, F. (2010). Governance Quality and Information Alignment.

Fehle, F. (2004). Bid-ask spreads and institutional ownership. Review of Quantitative Finance and Accounting, 22(4), 275-292.

Florackis, C., \& Ozkan, A. (2009). The impact of managerial entrenchment on agency costs: An empirical investigation using UK panel data. European Financial Management, 15(3), 497-528.

Ghaemi, M. H., \& Vatanparast, M. (2005). Investigating the role of accounting information in reducing information asymmetry in the Tehran Stock Exchange. Journal of Accounting and Auditing Review, 12(41), 85-103.

Haniffa, R., \& Hudaib, M. (2006). Corporate governance structure and performance of Malaysian listed companies. Journal of Business Finance \& Accounting, 33(7-8), 1034-1062.

Hassasyeganeh, Y. (2006), Corporate governance in Iran. Auditor Journal, 32, 40-32.

Heflin, F., \& Shaw, K. W. (2000). Blockholder ownership and market liquidity. Journal of Financial and Quantitative Analysis, 35(04), 621-633.

Hillier, D., \& McColgan, P. (2006). An analysis of changes in board structure during corporate governance reforms. European Financial Management, 12(4), 575-607.

Holm, C., \& Schøler, F. (2010). Reduction of asymmetric information through corporate governance mechanisms-The importance of ownership dispersion and exposure toward the international capital market. Corporate Governance: An International Review, 18(1), 32-47.

Jensen, M., \& Meckling, W. (1976). Theory of the firm: Managerial behaviours agency costs and ownership structure. Journal of Financial Economics, 3(4), 305-360. 
Kanagaretnam, K., Lobo, G. J., \& Whalen, D. J. (2005). Relationship Between Analyst Forecast Properties and Equity Bid-Ask Spreads and Depths Around Quarterly Earnings Announcements. Journal of Business Finance \& Accounting, 32(9-10), 1773-1799.

Kanagaretnam, K., Lobo, G. J., \& Whalen, D. J. (2007). Does good corporate governance reduce information asymmetry around quarterly earnings announcements?. Journal of Accounting and Public Policy, 26(4), 497-522.

Kang, S. H., Kumar, P., \& Lee, H. (2006). Agency and Corporate Investment: The Role of Executive Compensation and Corporate Governance*. The Journal of Business, 79(3), 1127-1147.

Klein, L. S., O’Brien, T. J., \& Peters, S. R. (2002). Debt vs. equity and asymmetric information: A review. Financial Review, 37(3), 317-349.

Miller, R. M. (2002). Can markets learn to avoid bubbles?. The Journal of Psychology and Financial Markets, 3(1), 44-52.

Morgado, A., \& Pindado, J. (2003). The underinvestment and overinvestment hypotheses: an analysis using panel data. European Financial Management,9(2), 163-177.

Nouravesh, A., \& Ebrahimi Kordlor, A. (2005). Investigating and explaining the relationship of shareholders with information symmetry and usefulness of accounting performance measures. Review of Accounting and Auditing, 42, 97-124.

O'Neill, M., \& Swisher, J. (2003). Institutional Investors and Information Asymmetry: An Event Study of Self-Tender Offers. Financial Review, 38(2), 197-211.

Parkinson, J.E. (1994). Corporate Power and Responsibility. Oxford University Press Oxford.

Pawlina, G., \& Renneboog, L. (2005). Is Investment-Cash Flow Sensitivity Caused by Agency Costs or Asymmetric Information? Evidence from the UK. European Financial Management, 11(4), 483-513.

Peasnell, K. V., Pope, P. F., \& Young, S. (2005). Board monitoring and earnings management: do outside directors influence abnormal accruals?. Journal of Business Finance \& Accounting, 32(78), 1311-1346.

Perotti, E. C., \& Thadden, V. (2003). Strategic transparency and informed trading: will capital market integration force convergence of corporate governance?. Journal of Financial and Quantitative Analysis, 38(01), 61-86.

Rahimian, Nezamodin, Salehnezhad, S.H., \& Saleki, A. (2009). The relationship between some mechanisms of corporate governance and information asymmetry in firms listed in Tehran Stock Exchange. Review of Accounting and Auditing, 16(58), 86-71.

Rahmani, A., et al. (2010). The relationship between institutional ownership and stock liquidity in Iran. Review of Accounting and Auditing, 17(61). 39-54.

Rutherford, M. A., \& Buchholtz, A. K. (2007). Investigating the relationship between board characteristics and board information. Corporate Governance: An International Review, 15(4), 576-584.

Shleifer, A., \& Vishny, R. W. (1997). A survey of corporate governance. The journal of finance, 52(2), 737-783.

Spence, M., Akerlof, G., \& Joseph, S. (1970). Markets with Asymmetric information.

Venkatesh, P. C., \& Chiang, R. (1986). Information asymmetry and the dealer's Bid-Ask spread: A case study of earnings and dividend announcements. The Journal of Finance, 41(5), 1089-1102.

Wruck, K. (1993). Stock-based incentives and investment decisions. Journal of Accounting \& Economics, 16(1-3), 373-380.

Zingales, L. (1998). Corporate Governance, The New Palgrave Dictionary of Economics and Law. MacMillan, London. 